\title{
Race Dynamics, Diversity, and Virulence Evolution in Puccinia strïformis f. sp. tritici, the Causal Agent of Wheat Stripe Rust in China from 2003 to 2007
}

\author{
W. Q. Chen, L. R. Wu, T. G. Liu, and S. C. Xu, State Key Laboratory for the Biology of Plant Diseases and Insect \\ Pests, Institute of Plant Protection, Chinese Academy of Agricultural Science, West Yuan Ming Yuan Road, Beijing \\ 100193, China; S. L. Jin, Institute of Plant Protection, Gansu Academy of Agricultural Science, Lanzhou 730030, \\ China; Y. L. Peng, Institute of Plant Protection, Sichuan Academy of Agricultural Science, Chengdu 610021, China; \\ and B. T. Wang, College of Plant Protection, Northwest Agriculture and Forestry University, Yangling 710004, China
}

\begin{abstract}
Chen, W. Q., Wu, L. R., Liu, T. G., Xu, S. C., Jin, S. L., Peng, Y. L., and Wang, B. T. 2009. Race dynamics, diversity, and virulence evolution in Puccinia striiformis f. sp. tritici, the causal agent of wheat stripe rust in China from 2003 to 2007. Plant Dis. 93:1093-1101.

Stripe (or yellow) rust caused by Puccinia striiformis f. sp. tritici is the most destructive foliar disease of wheat in China. The pathogen populations were analyzed for virulence evolution, complexity, phenotypic dynamics, and diversity on temporal and spatial bases. A total of 41 races were identified and characterized from 4,714 stripe rust isolates collected during 2003 through 2007 from wheat growing areas in 15 provinces in China. The races were based on avirulence/virulence patterns to 19 differential host genotypes. Chinese stripe rust population exhibited high diversity with a complex virulence structure. Comparisons using the relative Shannon's index indicated that some differences in the richness and evenness of races were present in pathogen populations within years and between regions despite a national tendency to reduced diversity over time. A noticeably increased frequency of race CYR33 (Chinese yellow rust 33) with virulence for $\mathrm{YrSu}$ was the major virulence change recorded in this study compared to the results on an annual basis. Isolates of Puccinia striiformis f. sp. tritici from different regions showed differences in the composition of races, distribution frequency, and diversity. The uneven distribution of major races and comparatively greater diversity in the Northwest and Southwest regions than that in the Huang-Huai-Hai region suggest that long-distance migrations of the pathogen occur from one or more over-summering areas eastward into over-wintering areas. This supports the hypothesis that southern Gansu and northwestern Sichuan comprises a "center of origin for virulence". Mutation of virulence or avirulence for host resistance in the stripe rust fungus may be the basic cause of the occurrence of new virulent types. The subsequent dominance of certain races will vary with parasitic fitness and the opportunities to be selected through large-scale cultivation of varieties with matching resistance genes. Implications of the center of origin for virulence variation and diversity in the pathogen population and an alternative strategy for limiting virulence evolution are discussed.
\end{abstract}

China is one of the largest producers of agricultural commodities in the world, including production and consumption of wheat. Wheat (Triticum aestivum L.) is annually grown on more than 22.8 million hectares, and the total wheat production exceeds 100 million metric tons (24). Stripe (yellow) rust, caused by Puccinia striiformis Westend. f. sp. tritici Eriks., is an economically important disease of wheat in many regions of the world $(5,15,27,28,39,40)$, and is considered the most destructive foliar disease of wheat in

Corresponding author: W. Q. Chen

E-mail: wqchen@ippcaas.cn

Accepted for publication 27 June 2009.

doi:10.1094/PDIS-93-11-1093

(C) 2009 The American Phytopathological Society of colleagues working for more than five decades $(1-4,30,45)$. Growing resistant cultivars is the most economical, environmentally friendly, and effective method to control stripe rust of wheat. More than 40 designated and many other temporarily designated $\mathrm{Yr}$ genes for resistance to stripe rust have been described in wheat, and some of them have been widely used in different areas worldwide $(21,22)$. However, when resistance to an obligate parasite such as rust is determined by a single gene, it is common to observe the evolution of a new race capable of overcoming the resistance within about 5 years $(36,38)$. This inevitably leads to disease epidemics of boom-bust cycles and has occurred in China in past years $(14,30,36,38)$. For example, wheat lines with $\operatorname{Yr} 9$ were widely used in wheat breeding programs throughout China since the 1960s, and more than $80 \%$ of the released cultivars contained $\operatorname{Yr} 9$ by the late 1980 s $(30,33)$. A new race of P. striiformis f. sp. tritici, CYR29 (Chinese yellow rust 29), with virulence to $\operatorname{Yr} 9$ was detected in 1985; this race led to the breakdown of resistance in wheat cultivars carrying $\mathrm{Yr} 9$, resulting in yield losses of 2.65 million tons in 1990. A similar situation occurred in 2002 as races CYR31 and CYR32 virulent to wheat variety Fan 6 and its derivatives with the resistant genes $\operatorname{Yr} 3 b$ and $Y r 4 b$ appeared (33).

Monitoring the dynamics and variation of virulence in rust populations provides the basis for anticipatory breeding of cultivars with optimum resistance levels, prediction of disease epidemics, and integrated control $(5,16,20)$. Surveys of $P$. striiformis $\mathrm{f}$. sp. tritici races in China were first conducted in the 1940s (6,7); a total of nine races ( $\mathrm{C} 1$ to $\mathrm{C} 9)$ were found at that time using seven wheat genotypes. Lu et al. (17) reported 16 races from 50 samples from eastern and northern China tested with 14 differential genotypes used by Gassner and Straib (8). During 1957 through 1961, 10 races (CYR1 to CYR10) were identified from 325 samples using a Chinese differential set (35). Annual surveys of races throughout major wheatgrowing areas have been conducted by the 
Institute of Plant Protection, Chinese Academy of Agricultural Science (IPP, CAAS) alone or with its cooperating institutes from the Chinese National Wheat Rust Collaborative Group (CNWRCG) since 1961, except for some irregularities from 1966 to 1971 (31-33,35,37,38,41). The major virulence patterns have been formally designated CYR races with sequential numbers based on their chronological appearance by the annual meeting of CNWRCG. Minor virulence patterns with low frequencies and limited distribution were temporarily nominated using the abbreviations of specific wheat differential genotypes. The composition of differential sets was supplemented and adjusted several times along with the changes of wheat commercial cultivars, but the race nomenclature system has remained relatively consistent since the 1960s. The current differential set consists of 19 wheat genotypes. By 2002, there were 32 CYR races of P. striiformis f. sp. tritici (CYR1 to CYR32) described in China using diverse sets of stripe rust differentials. Newly detected races tended to have a wider virulence spectrum than that of earlier ones $(32,33)$

Information from annual pathogenic variation of stripe rust and race frequencies have provided valuable data for wheat breeding programs and also helped to identify virulence evolution over time. Changes in races and their virulence have corresponded to changes in wheat cultivars deployed in commercial production
$(36,38)$. In recent years, more cultivars with various resistance genes have been released, especially in Gansu and Sichuan provinces, the most important oversummering and inoculum-source regions of $P$. striiformis f. sp. tritici in China

Table 1. Wheat differential lines and their $Y r$ genes used for race surveys of Puccinia striiformis $\mathrm{f} . \mathrm{sp}$. tritici in China during 2003 to 2007

\begin{tabular}{|c|c|c|c|}
\hline Serial no. & Name of wheat lines & Origins & Yr genes $^{\mathrm{z}}$ \\
\hline 1 & Trigo Eureka & & Yr6 \\
\hline 2 & Fulhard & & Unknown \\
\hline 3 & Lutescenes 128 & Bulgaria & Unknown \\
\hline 4 & Mentana & Italy & Unknown \\
\hline 5 & Virgilio & Italy & YrVir1,YrVir2 \\
\hline 6 & Abbondanza & Italy & Unknown \\
\hline 7 & Early Piemium & USA & Unknown \\
\hline 8 & Funo & Italy & $Y r A,+$ \\
\hline 9 & Danish 1 & Denmark & Yr3 \\
\hline 10 & Jubilejina 2 & Bulgaria & YrJu1,YrJu2, YrJu3, ҮrJu4 \\
\hline 11 & Fengchan 3 & China & Yrl \\
\hline 12 & Lovrin 13 & Romania & $Y r 9,+$ \\
\hline 13 & Kangyin 655 & & $\operatorname{Yr} 1, Y r K y 1, Y r K y 2$ \\
\hline 14 & Suwon 11 & Korea & $\mathrm{YrSu}$ \\
\hline 15 & Zhong 4 & China & Unknown \\
\hline 16 & Lovrin 10 & Romania & $\operatorname{Yr} 9$ \\
\hline 17 & Hybrid 46 & & $Y r 3 b, Y r 4 b$ \\
\hline 18 & Triticum spelta album & & Yr5 \\
\hline 19 & Guinong 22 & China & Unknown \\
\hline
\end{tabular}

${ }^{\mathrm{z}} \mathrm{Yr}$ genes were based on Stubbs (27), Yang et al. (44), Roelfs et al. (26), Line and Chen (16), McIntosh et al. (22), and Zhao et al. (46-48).

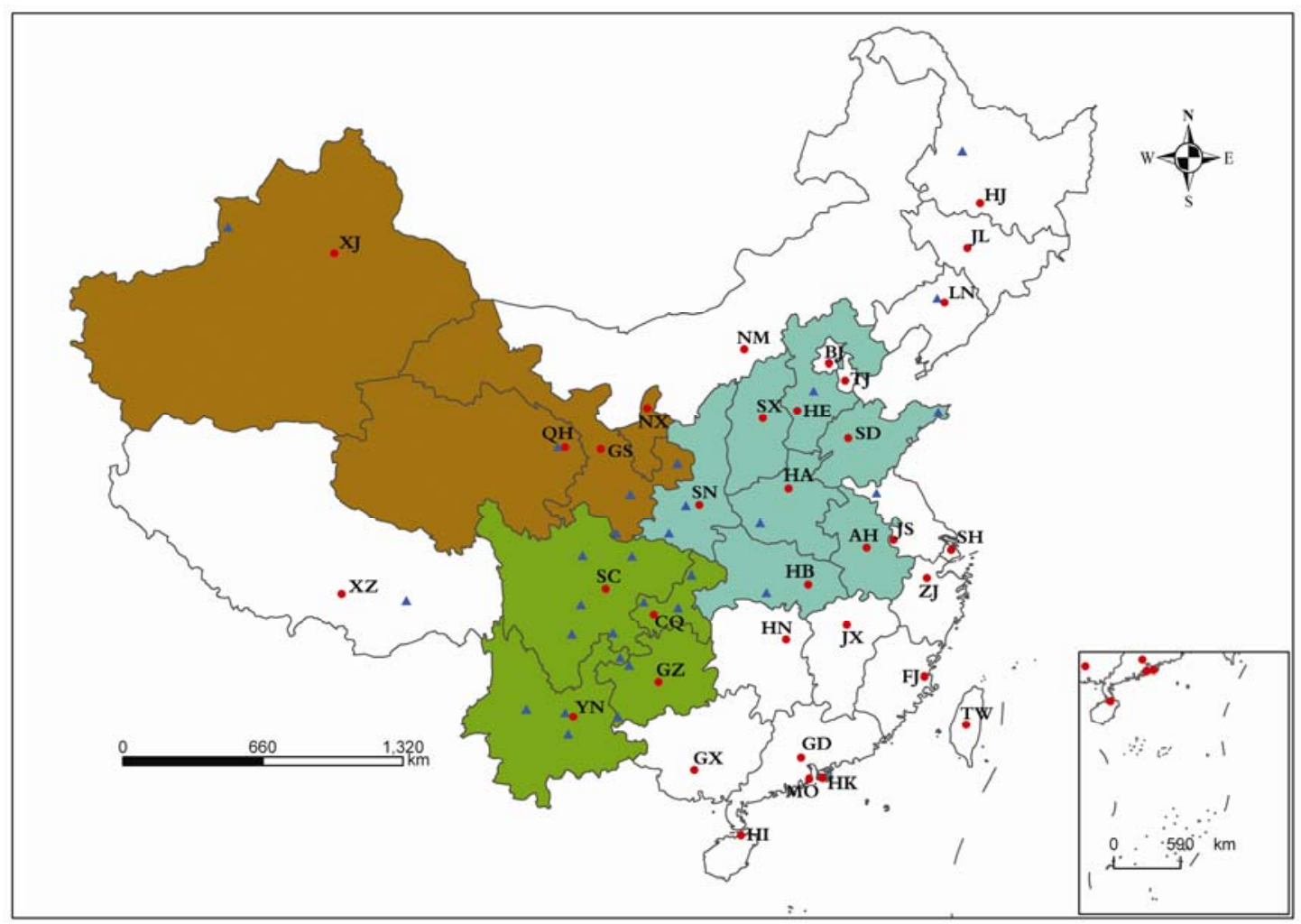

Fig. 1. Distribution of trap nurseries and source sites of urediniospore samples of Puccinia striiformis f. sp. tritici for virulence survey during 2003 to 2007. Colored areas represent provinces of sample sources (brown area: Northwest region; green area: Southwest region; and blue area: Huang-Huai-Hai region). $\mathrm{XJ}=$ Xinjiang autonomous region, $\mathrm{QH}=\mathrm{Q}$ inghai province, $\mathrm{GS}=$ Gansu province, $\mathrm{NX}=$ Ningxia autonomous region, $\mathrm{SC}=\mathrm{Sichuan}$ province, $\mathrm{YN}=\mathrm{Yuannan}$ province, $\mathrm{GZ}=$ Guizhou province, $\mathrm{CQ}=$ Chongqing city, $\mathrm{XZ}=$ Tibet autonomous region, $\mathrm{SN}=$ Shaanxi province, $\mathrm{SX}=\mathrm{Shanxi}$ province, $\mathrm{HA}=\mathrm{Henan}$ province, $\mathrm{HE}=$ Hebei province, $\mathrm{SD}=$ Shandong province, $\mathrm{AH}=$ Anhui province, $\mathrm{HB}=$ Hubei province, $\mathrm{BJ}=$ Beijing city, $\mathrm{TJ}=$ Tianjian city, $\mathrm{NM}=\mathrm{Inner}$ Mongolia autonomous region, $\mathrm{LN}=$ Liaoning province, $\mathrm{JL}=\mathrm{Jilin}$ province, $\mathrm{HJ}=$ Helongjiang province, $\mathrm{JS}=$ Jiangsu province, $\mathrm{ZJ}=\mathrm{Zhejiang}$ province, $\mathrm{SH}=$ Shanghai city, $\mathrm{HN}=$ Hunan province, $\mathrm{JX}=$ Jiangxi province, $\mathrm{GX}=$ Guangxi autonomous region, $\mathrm{GD}=$ Guangdong province, FJ = Fujian province, HI = Hainan province, $\mathrm{HK}=$ Hongkong autonomous region, $\mathrm{MO}=$ Macao autonomous region, and TW = Taiwan province. $\boldsymbol{\Lambda}$ Indicates location of trap nursery; $\bullet$ indicates location of provincial capitals. 
$(30,49)$. The objectives of this study were to characterize the virulence of $P$. striiformis f. sp. tritici populations in China during 2003 to 2007. General attributes within the pathogen populations, including virulence evolution, complexity, phenotype dynamics, and diversity on the temporal and spatial bases, were examined.

\section{MATERIALS AND METHODS}

Field surveys and isolate collections. Regular field surveys were conducted annually across wheat growing areas in China, especially in the inoculum source areas (e.g., southern Gansu and northwestern Sichuan), at seedling stage (late November to early December) and adult-plant stage (late April to early July) during 2003 to 2007. Infected wheat leaves were collected from trap nurseries and commercial wheat fields (Fig. 1). Date of collection, location, cultivar, severity, collector, and any other relevant information was recorded for each sample whenever possible. Diseased leaves were dispatched in paper envelopes for pathogenicity tests to the IPP, CAAS, and others were identified at Shaanxi, Gansu, and Sichuan provinces. Infected leaves were air-dried and stored at 4 to $5^{\circ} \mathrm{C}$ until spores were collected for inoculation and increase. A total of 4,714 stripe rust samples were collected from trap nurseries and wheat growing areas in 15 provinces in China from 2003 to 2007, of which $3,950(83.8 \%)$ originated from Gansu, Sichuan, and Shaanxi, where the most frequent stripe rust epidemics occurred.

Trap nurseries. Trap nurseries contained 130 wheat genotypes, including wheat cultivars, important resistant materials, differentials, and near-isogenic $\mathrm{Yr}$ gene lines and highly susceptible lines (cv. Mingxian 169). The nurseries were planted at 29 locations in 16 provinces of Gansu, Shaanxi, Qinghai, Xinjiang, Sichuan, Yunnan, Guizhou, Chongqing, Tibet, Henan, Hebei, Shandong, Hubei, Jiangsu, Liaoning, and Helongjiang during the 2007 growing season to monitor rust development and virulence, and to determine effectiveness of resistance. Disease severity and infection type were recorded during the flowering to soft dough stages using the modified Cobb scale (26).

Identification of race and virulence. Rust collections were assessed separately in the IPP, CAAS in Beijing and in the Academies of Agricultural Sciences of Shaanxi, Gansu, and Sichuan. Air-dried leaves with urediniospores were incubated on water-soaked tissue paper in petri dishes in the dark at $4^{\circ} \mathrm{C}$ for 10 to $15 \mathrm{~h}$. Urediniospores from each collection were multiplied by inoculating 7-day-old seedlings of susceptible wheat genotype Mingxian 169. Inoculated plants were kept in a dew chamber overnight at $10^{\circ} \mathrm{C}$ and then moved to greenhouse benches at 15 to $18^{\circ} \mathrm{C}$ supplemented with $10,000 \mathrm{~lx}$ of fluo- rescent light for $10 \mathrm{~h}$ per day. The second leaves were clipped when chlorotic spots appeared on leaves ( $\sim$ days postinoculation), and the plants were covered with a glass cylinder to prevent cross contamination. Urediniospores of each isolate were collected 15 days after inoculation and temporarily kept in a dryer at low temperature $\left(3\right.$ to $\left.4^{\circ} \mathrm{C}\right)$. A set of 19 differential wheat genotypes was used to determine races of $P$. striiformis f. sp. tritici (Table 1). Sets of differentials were planted in 10$\mathrm{cm}$-diameter pots containing a mixture of commercial peat moss and soil, each with four wheat genotypes (five to seven plants per line), and grown in a rust-free greenhouse. About 10 days after planting, when the first leaf was fully extended, seedlings were inoculated with fresh urediniospores by using a spatula or spraying a spore suspension (Soltrol 170, Phillips 66 Company,
OK, USA). Inoculated plants were transferred to a dew chamber and then to greenhouse benches under the same temperature and light conditions described above. Infection type (IT) data of the plant-pathogen interactions were recorded 15 to 20 days after inoculation when the disease was fully developed. Races of $P$. striiformis $\mathrm{f}$. sp. tritici were determined by IT based on the 0 to 4 scale (27), i.e., no visible symptoms (IT 0), necrotic or chlorotic flecks (IT ;), necrotic or chlorotic blotches with very low level of sporulation (IT 1), moderate uredinia with necrosis/chlorosis (IT 2), moderate to abundant uredinia with chlorosis (IT 3), and abundant uredinia without necrosis and chlorosis (IT 4). Infection types 0 to 2 were considered avirulent, and 3 to 4 virulent. The results obtained were based mostly on single tests, but if an infection type was not

Table 2. Race frequencies of Puccinia striiformis f. sp. tritici detected in China during 2003 to 2007 and their virulence spectra on 19 Chinese differential hosts

\begin{tabular}{|c|c|c|c|}
\hline Race group $^{w}$ & Race name $^{x}$ & Avirulence / virulence formula ${ }^{y}$ & $F(\%)^{\mathrm{z}}$ \\
\hline & CYR17 & $3,5,8,9,10,11,12,13,14,15,16,17,18,19 / 1 ?, 2,4 ?, 6 ?, 7$ & $<1$ \\
\hline & CYR18 & $1,2,4,5,7,8,10,11,12,13,14,15,16,17,18,19 / 3,6,9$ & $<1$ \\
\hline & CYR19 & $1,5,10,12,13,14,15,16,17,18,19 / 2,3,4,6,7,8,9,11$ & $<1$ \\
\hline & CYR21 & $5,12,13,14,15,16,17,18,19 / 1 ?, 2,3,4,6,7,8 ?, 9 ?, 10,11$ & $<1$ \\
\hline & CYR22 & $5,12,14,15,16,17,18,19 / 1,2,3,4,6,7,8,9 ?, 10,11,13$ & $<1$ \\
\hline & CYR23 & $5,10,12,13,14,15,16,17,18,19 / 1,2,3,4,6,7,8,9,11$ & $<1$ \\
\hline & CYR24 & $5,9,10,12,13,14,15,16,17,18,19 / 1 ?, 2,3,4,6,7,8,11$ & $<1$ \\
\hline & CYR25 & $10,12,13,14,15,16,17,18,19 / 1 ?, 2,3,4,5,6,7,8 ?, 9 ?, 11$ & $<1$ \\
\hline & CYR26 & $5,10,12,13,14,15,16,17,18,19 / 1 ?, 2,3,6,7,8,9,11$ & $<1$ \\
\hline & CYR27 & $12,14,15,16,17,18,19 / 1,2,3,4,5,6,7,8,9,10,11,13$ & $<1$ \\
\hline \multirow[t]{9}{*}{ LvG } & CYR28 & $10,12,13,14,15,17,18,19 / 1,2,3,4,5,6,7,8,9,11,16$ & $<1$ \\
\hline & CYR29 & $10,13,14,15,17,18,19 / 1,2,3,4,5,6,7,8,9,11,12,16$ & $<1$ \\
\hline & Lv10-2 & $4,5,10,12,13,14,15,17,18,19 / 1,2,3,6,7,8,9,11,16$ & $<1$ \\
\hline & Lv10-3 & $1,5,10,12,13,14,15,17,18,19 / 2,3,4,6,7,8,9,11,16$ & $<1$ \\
\hline & Lv10-5 & $5,10,12,13,14,15,17,18,19 / 1,2,3,4,6,7,8,9,11,16$ & $<1$ \\
\hline & Lv10-6 & $5,12,13,14,15,17,18,19 / 1,2,3,4,6,7,8,9,10,11,16$ & $<1$ \\
\hline & Lv13-2 & $4,5,10,13,14,15,17,18,19 / 1,2,3,6,7,8,9,11,12,16$ & $<1$ \\
\hline & Lv13-3 & $14,15,17,18,19 / 1,2,3,4,5,6,7,8,9,10,11,12,13,16$ & $<1$ \\
\hline & Lv13-8 & $13,14,15,17,18,19 / 1,2,3,4,5,6,7,8,9,10,11,12,16$ & $<1$ \\
\hline \multirow[t]{9}{*}{ HyG } & CYR30 & $10,13,14,15,18,19 / 1,2,3,4,5,6,7,8,9,11,12,16,17$ & 1.1 \\
\hline & CYR31 & $10,13,15,18,19 / 1,2,3,4,5,6,7,8,9,11,12,14,16,17$ & 3.6 \\
\hline & CYR32 & $15,18,19 / 1,2,3,4,5,6,7,8,9,10,11,12,13,14,16,17$ & 29.6 \\
\hline & Нy46-4 & $12,15,18,19 / 1 ?, 2,3,4,5,6,7,8,9,10,11,13,14,16,17$ & $<1$ \\
\hline & Hy46-5 & $12,15,18,19 / 1,2,3,4,5 ?, 6,7,8,9,10,11,13,14,16,17$ & $<1$ \\
\hline & Hy46-6 & $10,12,13,15,16,18,19 / 1 ?, 2,3,4,5,6,7,8 ?, 9 ?, 11,14,17$ & 1.1 \\
\hline & Нy46-7 & $1,15,18,19 / 2,3,4,5 ?, 6,7,8,9,10,11,12,13,14,16,17$ & 2.2 \\
\hline & Hy46-8 & $13,15,18,19 / 1 ?, 2,3,4,5 ?, 6,7,8,9,10,11,12,14,16,17$ & 2.9 \\
\hline & Нy46-9 & $12,15,18,19 / 1,2,3,4,5 ?, 6,7,8,9,10,11,13,14,17$ & $<1$ \\
\hline \multirow[t]{13}{*}{ SuG } & CYR33 & $15,18,19 / 1 ?, 2,3,4,5 ?, 6,7,8,9,10,11,12,13,14,16$ & 17.4 \\
\hline & Su11-1 & $3,4,5,6,8,9,10,11,12,13,15,16,17,18,19 / 1,2,7,14$ & 1.6 \\
\hline & Su11-2 & $10,12,13,15,16,17,18,19 / 1,2,3,4,5,6,7,8,9,11,14$ & 1.2 \\
\hline & Su11-3 & $12,15,16,17,18,19 / 1 ?, 2,3,4,5,6,7,8,9,10,11,13,14$ & 1.1 \\
\hline & Su11-4 & $1,5,11,12,15,17,18,19 / 2,3,4,6,7,8,9,10,13,14,16$ & 6.2 \\
\hline & Su11-5 & $10,12,13,15,17,18,19 / 1,2,3,4,5 ?, 6,7,8,9,11,14,16$ & 4.2 \\
\hline & Su11-6 & $4,5,10,12,13,15,16,17,18,19 / 1,2,3,6,7,8,9,11,14$ & 1.7 \\
\hline & Su11-7 & $10,13,15,17,18,19 / 1,2,3,4,5 ?, 6,7,8,9,11,12,14,16$ & 5.5 \\
\hline & Su11-8 & $5,10,12,13,15,16,17,18,19 / 1,2,3,4,6,7,8,9,11,14$ & 1.2 \\
\hline & Su11-10 & $1,5,10,12,13,15,16,17,18,19 / 2,3,4,6,7,8,9,11,14$ & 1.1 \\
\hline & Su11-11 & $5,12,15,16,17,18,19 / 1,2,3,4,6,7,8,9,10,11,13,14$ & 2.3 \\
\hline & Su11-12 & $1,4,5,10,12,13,15,17,18,19 / 2,3,6,7,8,9,11,14,16$ & 1.7 \\
\hline & Su11-13 & $5,12,13,15,16,17,18,19 / 1,2,3,4,6,7,8,9,10,11,14$ & 1.8 \\
\hline
\end{tabular}

${ }^{\mathrm{w}} \mathrm{LvG}=$ Race group virulence for Lovrin 10/Lovrin $13(\mathrm{Yr} 9) ; \mathrm{HyG}=$ race group virulence for Hybrid $46(\mathrm{Yr} 3 b, \mathrm{Yr} 4 b)$; and $\mathrm{SuG}=$ race group virulence for Suwon $11(\mathrm{YrSu})$.

${ }^{x} \mathrm{CYR}=$ Chinese yellow rust $\mathrm{Lv}=$ Lovrin; $\mathrm{Hy}=$ Hybrid; and $\mathrm{Su}=$ Suwon.

y Avirulence $=$ infection types $0-2$, and virulence $=$ infection types $3-4 ; ?=$ segregation of resistant and susceptible plants but more susceptible.

${ }^{\mathrm{z}}$ Weighted average frequencies $(\%)$ of 5 years from 2003 to 2007 were calculated as $F(\%)=$ $\sum(N i \cdot P i) / N \cdot 100 \%$, in which $P i$ is frequency of races in $i$ th year, $N i$ is number of isolates tested in $i$ th year, and $N$ is total number of isolates in 5 years. 
conclusive, the test was repeated. For a new virulence pattern, urediniospores were usually separated in water agar for single spore isolates. Races were designated using CYR numbering based on the chronological order of appearance or using the abbreviations of specific wheat differential genotypes.

Race diversity measurements. Frequencies of races within the population collected during different years or diverse geographical regions of China were compared. The regions are distinguished by climatic conditions, agronomic characteristics, and pathogen life cycle features $(2,45,50)$. The relative Shannon index $\left(H_{S R}\right)$ was calculated from data on races of $P$. striiformis f. sp. tritici from different regions and years $(9,23)$ :

$$
H_{S R}=-\sum(P j \cdot \ln P j) / \ln N i
$$

in which $P j$ is the frequency of the $j$ th race in the sample and $\mathrm{Ni}$ is the total number of isolates in the sample.

The Shannon indices between different regions and years were compared statisti- cally by the $t$ test using Statistical Analysis System (SAS) software.

\section{RESULTS}

Frequencies of races. Forty-one races were identified and characterized from the 4,714 stripe rust samples based on their avirulence/virulence patterns to the 19 differential genotypes. The weighted average frequencies of each race detected in 5 years are presented in Table 2. No isolates virulent to Zhong $4(\mathrm{Yr}+)$, Triticum spelta album $(Y r 5)$, or Guinong $22(Y r+)$ were found. All races were virulent to Fulhard $(Y r+)$ and Early Premium $(Y r+)$ except CYR18, and all were virulent to Abbondanza $(\mathrm{Yr}+)$ except Su11-1. CYR32 had the widest virulence spectrum and combined virulence for differential genotypes Lovrin 10 or Lovrin 13 (Yr9), Hybrid 46 $(\mathrm{Yr} 3 b, 4 b)$, and Suwon $11(\mathrm{YrSu})$, whereas CYR18 had the narrowest virulence spectrum, possessing virulence for only three differentials, i.e., Lutescenes $(Y r+)$, Abbondanza $(Y r+)$, and Danish 1 (Yr3).

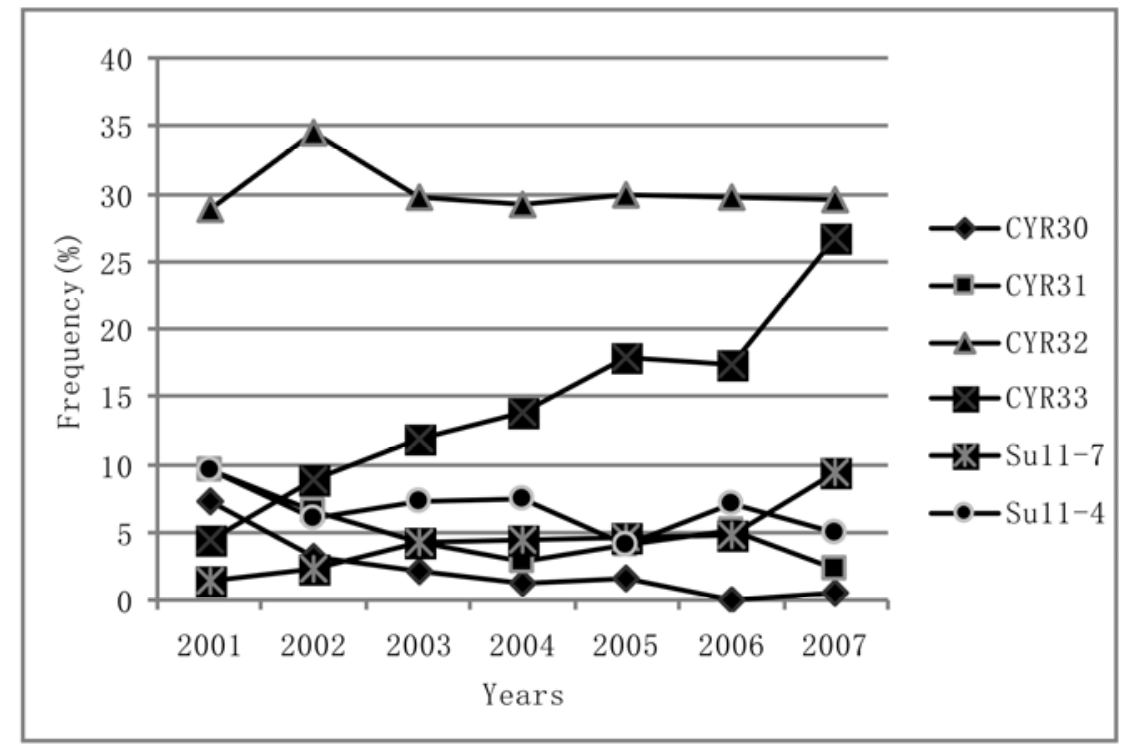

Fig. 2. Dynamics of major races of Puccinia striiformis f. sp. tritici in China from 2001 to 2007.
Races CYR17 to CYR27 were first detected before 1980, and the remaining 31 races were found after 1980 . The latter can be classified into three race groups, i.e., Lovrin group (LvG) with 9 races, Hybrid 46 group (HyG) with 9 races, and Suwon 11 group ( $\mathrm{SuG}$ ) with 13 races according to their avirulence/virulence patterns on differential genotypes Lovrin 10, Lovrin 13, Hybrid 46, and Suwon 11. Nine of the 41 races (CYR32, CYR33, Su11-4, Su11-7, Su11-5, CYR31, Su11-11, and Hy46-7) were the most common, with frequencies of $29.61,17.37,6.21,5.50,4.20,3.59$, $2.86,2.27$, and $2.23 \%$, respectively, during 2003 to 2007, while others remained at less than 2\% (Table 2). Races CYR18, CYR19, CYR27, CYR30, Lv10-3, Lv13-2, and Hy46-4 were sporadically detected in certain years or in some regions and remained less than $1 \%$ in frequency during 2003 to 2007 . The most frequently identified race in the past 5 years was CYR32, which comprised $29.61 \%$ nationwide and was distributed in all 15 sampled provinces. CYR33 was the second most frequent race and comprised $17.37 \%$ nationwide and was distributed in all sampled provinces except Shandong. Both CYR32 and CYR33 played a major role in causing the widespread epidemics of wheat stripe rust in China in recent years.

Dynamics of major races. Compared with the frequencies of the major races from year to year during 2001 to 2007 , the frequencies of CYR33 and Su11-7 increased from 4.21 and $1.50 \%$ in 2001 to 26.72 and $9.46 \%$ in 2007 , respectively, while the frequencies of CYR30, CYR31, and Su11-4 decreased from 7.33, 9.51, and $9.51 \%$ in 2001 to $0.51,2.26$, and $4.93 \%$ in 2007, respectively (Fig. 2). CYR32 was first detected in 1994, became predominant in 2000 with a frequency of $11 \%$, and dramatically increased to $28.79 \%$ in 2001 and $34.60 \%$ in 2002 (33). This race later declined somewhat but remained at frequencies of 29.23 to $29.97 \%$ during 2003 to 2007. CYR33 (old Su11-14), first found in 1997 with a frequency of less than $1 \%$,

Table 3. Distribution of 12 prevalent races of Puccinia striiformis f. sp. tritici in areas of China identified in 2003 to $2007^{z}$

(continued on next page)

\begin{tabular}{|c|c|c|c|c|c|c|c|c|c|c|c|c|c|c|}
\hline \multirow[b]{2}{*}{ Phenotype } & \multicolumn{2}{|c|}{ Henan } & \multicolumn{2}{|c|}{ Hebei } & \multicolumn{2}{|c|}{ Shandong } & \multicolumn{2}{|c|}{ Shanxi } & \multicolumn{2}{|c|}{ Hubei } & \multicolumn{2}{|c|}{ Shaanxi } & \multicolumn{2}{|c|}{ Gansu } \\
\hline & \# & $\%$ & \# & $\%$ & \# & $\%$ & \# & $\%$ & \# & $\%$ & \# & $\%$ & \# & $\%$ \\
\hline CYR28 & 0 & 0 & 0 & 0 & 0 & 0 & 0 & 0 & 0 & 0 & 8 & 0.7 & 2 & 0.1 \\
\hline CYR29 & 0 & 0 & 0 & 0 & 0 & 0 & 0 & 0 & 1 & 1.7 & 17 & 1.6 & 12 & 0.7 \\
\hline CYR30 & 0 & 0 & 0 & 0 & 0 & 0 & 0 & 0 & 0 & 0 & 3 & 0.3 & 4 & 0.2 \\
\hline CYR31 & 3 & 3.7 & 0 & 0 & 0 & 0 & 0 & 0 & 6 & 10.0 & 69 & 6.4 & 30 & 1.8 \\
\hline CYR32 & 25 & 30.9 & 5 & 21.7 & 6 & 54.5 & 5 & 11.4 & 3 & 20.0 & 402 & 37.2 & 370 & 21.6 \\
\hline CYR33 & 5 & 6.2 & 3 & 13.0 & 0 & 0 & 7 & 15.9 & 8 & 13.3 & 186 & 17.2 & 472 & 27.5 \\
\hline Нy46-7 & 4 & 4.9 & 0 & 0 & 0 & 0 & 0 & 0 & 7 & 11.7 & 10 & 0.9 & 15 & 0.9 \\
\hline Нy46-8 & 7 & 8.6 & 0 & 0 & 2 & 18.2 & 1 & 2.3 & 3 & 5.0 & 4 & 0.4 & 47 & 2.7 \\
\hline Su11-4 & 3 & 3.7 & 9 & 39.1 & 1 & 9.1 & 8 & 18.2 & 5 & 8.3 & 66 & 6.1 & 120 & 7.0 \\
\hline Su11-5 & 1 & 1.2 & 0 & 0 & 0 & 0 & 5 & 11.4 & 2 & 3.3 & 34 & 3.1 & 110 & 6.4 \\
\hline Su11-7 & 2 & 2.5 & 0 & 0 & 0 & 0 & 0 & 0 & 3 & 5.0 & 32 & 3.0 & 180 & 10.5 \\
\hline Su11-11 & 4 & 4.9 & 0 & 0 & 0 & 0 & 0 & 0 & 5 & 8.3 & 48 & 4.4 & 10 & 0.6 \\
\hline Others & 27 & 33.3 & 6 & 26.1 & 2 & 18.2 & 18 & 40.9 & 17 & 28.3 & 203 & 18.8 & 342 & 20.0 \\
\hline Total & 81 & & 23 & & 11 & & 44 & & 60 & & 1,082 & & 1,714 & \\
\hline
\end{tabular}

${ }^{\mathrm{z}}$ Anhui (3 samples) and Ningxia (2 samples) not included in Table 4 due to the low sample sizes. 
increased year by year from $4.21 \%$ in 2001 to $26.72 \%$ in 2007 , and was formally named CYR33 in 2008. Su11-7 was first found in 1995 and slightly increased year by year to nearly $10 \%$ in 2007 . A noticeably increased frequency of CYR33 with virulence to $\mathrm{YrSu}$ was the major virulence change recorded in this study compared with the results on an annual basis (Fig. 2) and with that before 2003 (33). During the late 1990 s to early 2000s, cultivars with $\mathrm{YrSu}$ were grown in China, especially in the Northwest wheat growing areas where most likely races with virulence to $\mathrm{YrSu}$ were selected. The weighted average frequencies of Su11-5, Hy46-7, and Hy46-8 in 2003 to 2007 were $4.20,2.86$, and $2.23 \%$, respectively, but slightly fluctuated between 0.11 and $6.28 \%$ on an annual basis (data not shown).

Distribution and diversity of races. The distribution and frequencies of some important races in 13 sampled provinces of China in the course of this study are presented in Table 3. Anhui and Ningxia were excluded due to small sample size. Data in Table 3 show that isolates of $P$. striiformis f. sp. tritici from different regions displayed obvious differences in the composition, distribution, and diversity of races. Race CYR32 was widely distributed throughout all 13 provinces, with frequencies from $11.4 \%$ in Shanxi to $54.5 \%$ in Shandong, whereas CYR28 virulence for Lovrin $10(\operatorname{Yr} 9)$ but avirulence for Lovrin $13($ Yr9+) was restricted to only the three provinces of Sichuan, Shaanxi, and Gansu. CYR29 with virulence to both Lovrin 10 and Lovrin 13 was evident in the four provinces of Sichuan, Shaanxi, Hubei, and Gansu, with frequencies of 0.7 to $1.8 \%$. Su11-4 was also distributed in the 13 provinces with frequencies varying from $2.2 \%$ in Guizhou to $39.1 \%$ in Hebei. CYR33 was the third widely detected race and was distributed in all provinces except Shandong with frequencies of $2.6 \%$ in Guizhou and $27.5 \%$ in Gansu. The presence of races CYR32 and CYR33 in western provinces as well as in the wider eastern regions suggested that some movement of stripe rust occurred from the western regions eastward into the central and eastern regions. Race Hy46-8 was detected in 11 provinces with frequencies ranging from $0.4 \%$ in Shaanxi to $15.4 \%$ in Guizhou. Su11-5 was also found in 11 provinces with frequencies from $1.2 \%$ in Henan to $11.4 \%$ in Shanxi. Both races Hy46-7 and Su11-11 were detected in nine provinces with frequencies ranging from 0.9 to $9.9 \%$ and 0.6 to $9.9 \%$, respectively. CYR31 and Su11-7 were detected in eight provinces with frequencies ranging from 1.8 to $10.0 \%$ and from 2.5 to $10.5 \%$. CYR30 was not found in Henan, Hebei, Shandong, Shanxi, Hubei, Chongqing, Guizhou, and Qinghai, which are generally the overwintering areas of stripe rust in China. Results indicated that there were also great differences in the composition of the predominant races in various regions (Tables 2 and 3). CYR32 was the most dominant race with the highest frequency (above $20 \%$ ) in the majority of wheat growing areas. CYR33 was also predominant with a frequency of $27.5 \%$ in Gansu. Su11-4 was especially common in Hebei and Shanxi with frequencies of 39.1 and $18.2 \%$, respectively, although the sample sizes were small. Race group ( $\mathrm{SuG}$ ) virulence to $\mathrm{YrSu}$ consisted of 13 races (CYR33, Su11-1, Su11-2, Su11-3, Su11-4, Su11-5, Su11-6, Su11-7, Su11-8, Su11-10, Su11-11, Su1112, and Su11-13) and comprised of $48.15 \%$ of the samples in 2003 to 2007 (Table 2 and Fig. 3). This group was most frequent in the Northwest regions, with frequencies of up to $64.15 \%$. Nine races (CYR30, CYR31, CYR32, Hy46-4, Hy465, Hy46-6, Hy46-7, Hy46-8, and Hy46-9) formed the second race group ( $\mathrm{HyG})$ virulent to $Y r 3 b$ and $Y r 4 b$, which comprised $44.21 \%$ of the samples in 2003 to 2007 and was most commonly detected in the Southwest regions with frequencies of

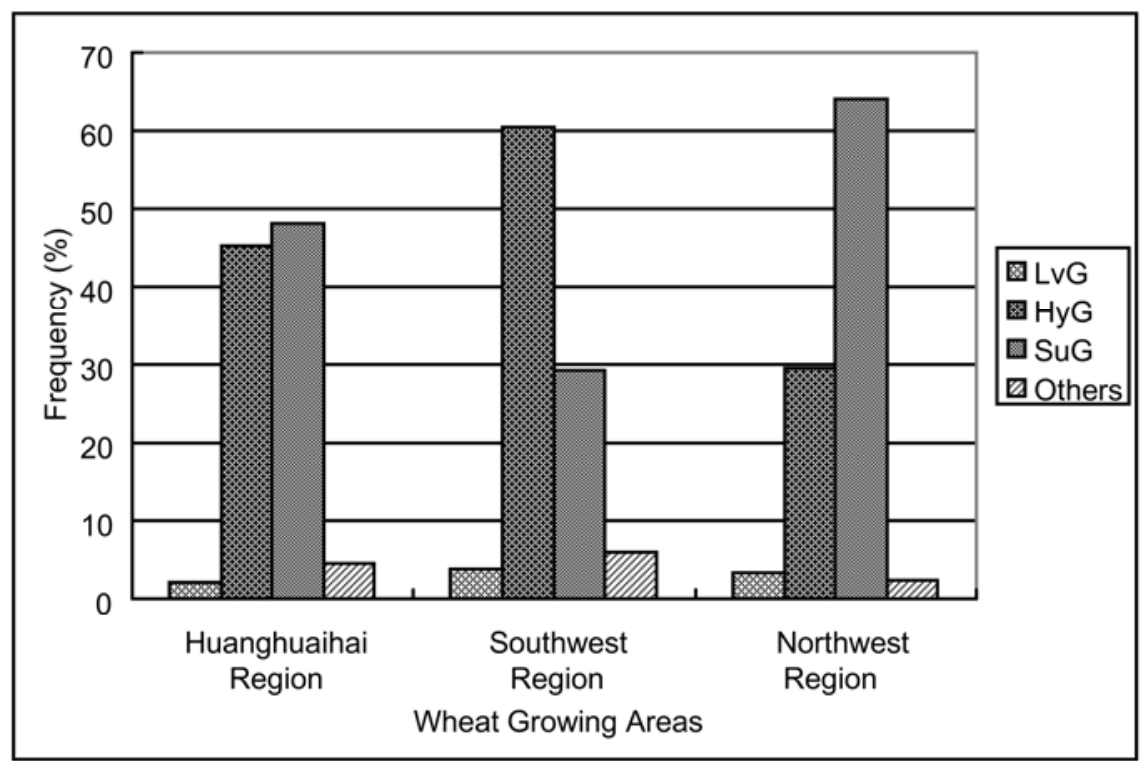

Fig. 3. Distribution of major race groups of Puccinia striiformis f. sp. tritici in China during 2003 to 2007. $\mathrm{LvG}=$ Race group virulence for Lovrin 10 and Lovrin $13(\mathrm{Yr} 9) ; \mathrm{HyG}=$ race group virulence for Hybrid $46(\mathrm{Yr} 3 b, \mathrm{Yr} 4 b)$; and $\mathrm{SuG}=$ race group virulence for Suwon $11(\mathrm{YrSu})$.

Table 3. (continued from preceding page)

\begin{tabular}{|c|c|c|c|c|c|c|c|c|c|c|c|c|c|c|}
\hline \multirow[b]{2}{*}{ Phenotype } & \multicolumn{2}{|c|}{ Qinghai } & \multicolumn{2}{|c|}{ Xinjiang } & \multicolumn{2}{|c|}{ Sichuan } & \multicolumn{2}{|c|}{ Yunnan } & \multicolumn{2}{|c|}{ Guizhou } & \multicolumn{2}{|c|}{ Chongqing } & \multicolumn{2}{|c|}{ Total } \\
\hline & $\#$ & $\%$ & $\#$ & $\%$ & $\#$ & $\%$ & \# & $\%$ & \# & $\%$ & \# & $\%$ & \# & $\%$ \\
\hline CYR28 & 0 & 0 & 0 & 0 & 11 & 1.0 & 0 & 0 & 0 & 0 & 0 & 0 & 21 & 0.4 \\
\hline CYR29 & 0 & 0 & 0 & 0 & 21 & 1.8 & 0 & 0 & 0 & 0 & 0 & 0 & 51 & 1.1 \\
\hline CYR30 & 0 & 0 & 1 & 3.8 & 44 & 3.8 & 1 & 0.3 & 0 & 0 & 0 & 0 & 53 & 1.1 \\
\hline CYR31 & 0 & 0 & 1 & 3.8 & 52 & 4.5 & 6 & 1.9 & 2 & 5.1 & 0 & 0 & 166 & 3.5 \\
\hline CYR32 & 28 & 31.8 & 6 & 23.1 & 368 & 31.9 & 136 & 43.0 & 12 & 30.8 & 21 & 29.6 & 1387 & 29.5 \\
\hline CYR33 & 7 & 8.0 & 2 & 7.7 & 98 & 8.5 & 22 & 7.0 & 1 & 2.6 & 7 & 9.9 & 818 & 17.4 \\
\hline Hy46-7 & 6 & 6.8 & 0 & 0 & 28 & 2.4 & 31 & 9.8 & 1 & 2.6 & 7 & 9.9 & 109 & 2.3 \\
\hline Нy46-8 & 3 & 3.4 & 0 & 0 & 49 & 4.2 & 10 & 3.2 & 6 & 15.4 & 2 & 2.8 & 133 & 2.8 \\
\hline Su11-4 & 14 & 15.9 & 2 & 7.7 & 50 & 4.3 & 7 & 2.2 & 4 & 10.3 & 3 & 4.2 & 291 & 6.2 \\
\hline Su11-5 & 8 & 9.1 & 1 & 3.8 & 33 & 2.9 & 4 & 1.3 & 1 & 2.6 & 2 & 2.8 & 201 & 4.3 \\
\hline Su11-7 & 3 & 3.4 & 0 & 0 & 33 & 2.9 & 5 & 1.6 & 0 & 0 & 3 & 4.2 & 261 & 5.5 \\
\hline Su11-11 & 5 & 5.7 & 1 & 3.8 & 13 & 1.1 & 10 & 3.2 & 0 & 0 & 7 & 9.9 & 102 & 2.2 \\
\hline Others & 14 & 15.9 & 12 & 46.2 & 354 & 30.7 & 84 & 26.6 & 12 & 30.8 & 19 & 26.8 & 1110 & 23.6 \\
\hline Total & 88 & & 26 & & 1,154 & & 316 & & 39 & & 71 & & 4,709 & \\
\hline
\end{tabular}


$60.44 \%$ (Table 2 and Fig. 3). The third race group $(\mathrm{LvG})$ was virulent to $\operatorname{Yr} 9$ consisting of nine races (CYR28, CYR29, Lv10-2, Lv10-3, Lv10-5, Lv10-6, Lv13-2, Lv13-3, and Lv13-8). This group was infrequently detected in all three wheat growing regions (Table 2 and Fig. 3). Different wheat genotypes planted in various wheat growing regions may be the underlying cause of the spatial variability for the distribution of races in China.
The $P$. striiformis f. sp. tritici population in China is highly diverse, with more than 41 races present during 2003 to 2007 (Table 4). The diversity of races within population-years and between populationregions was calculated using relative Shannon index $\left(H_{S R}\right)$ (Tables 4). The $H_{S R}$ value varied between 0.3329 and 0.4098 within years across all wheat growing regions. In general, $H_{S R}$ values did not differ significantly between years in the

Table 4. Total numbers of isolates tested, races detected of Puccinia striiformis f. sp. tritici, and Shannon's index in different years, and wheat growing regions of China during 2003 to 2007

\begin{tabular}{lccc}
\hline Years or regions $^{\mathbf{y}}$ & Isolates tested & Race numbers detected & $\boldsymbol{H}_{\boldsymbol{S R}}^{\mathbf{z}}$ \\
\hline 2003 & 955 & 41 & $0.4097 \mathrm{a}$ \\
2004 & 1,194 & 40 & $0.3867 \mathrm{a}$ \\
2005 & 871 & 38 & $0.3920 \mathrm{a}$ \\
2006 & 721 & 36 & $0.3918 \mathrm{a}$ \\
2007 & 973 & 37 & $0.3329 \mathrm{~b}$ \\
Huang-Huai-Hai regions & 1,304 & 34 & $0.3405 \mathrm{~b}$ \\
Southwest regions & 1,580 & 39 & $0.3615 \mathrm{ab}$ \\
Northwestern regions & 1,830 & 41 & $0.3752 \mathrm{a}$ \\
Total & 4,714 & - & - \\
\hline
\end{tabular}

y Huang-Huai-Hai region includes Henan, Hebei, Shandong, Shanxi, Shaanxi, Anhui, and Hubei provinces; Southwest region includes Sichuan, Yunnan, Guizhou, and Chongqing provinces (or cities); and Northwest region includes Gansu, Qinghai, Ningxia, and Xinjiang provinces (or municipalities).

${ }^{\mathrm{z}}$ Different lowercase letters indicate significant difference at $P=0.05$.

Year of

1966

1972

1978

1985

1991

1993

1994

1995 emergence

Races and presumptive mutation

(a)

\section{CYR17}

+ Funo $(Y r A)$

+ Danishi $1($ Yr3)

+ Lutescenes 128

$\checkmark$ - Trigo Eureka (Yro)

CYR19

${ }^{+}+$Trigo Eureka $(\operatorname{Yr} \sigma)$

+ Virgilio (YrVir1,Vir2)

CYR25

+ Lovrin $10(Y r 9)$

+ Lovrin $13(Y r 9,+)$

CYR29

40.3

1989
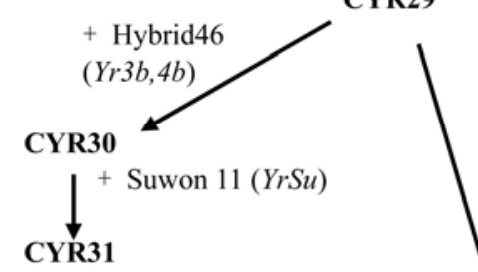

(YrSu)
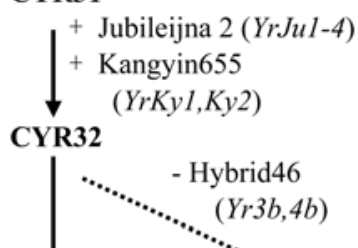

$(Y r 3 b, 4 b)$
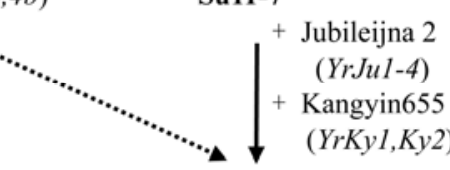

1997

CYR33 course of this study (0.4097 in 2003, 0.3867 in $2004,0.3920$ in $2005,0.3918$ in 2006, and 0.3329 in 2007), indicating that the richness of $P$. striiformis f. sp. tritici races and their relative dominance remained relatively stable in China from 2003 to 2007 despite the constant directional selection for different virulences. However, some differences in diversity were detected within population-years. The greatest Shannon index (0.4097) for diversity of races was observed in 2003 , and the smallest index (0.3329) in 2007. This probably reflects a tendency toward reduction in the diversity of races over time. Comparison of relative Shannon indices indicated no greater differences in the richness and evenness of races among three regions despite the fact that the number of races detected in the Northwest and Southwest wheat growing regions was much greater than that in the Huang (Yellow) River, Huai River, and Hai River regions (Huang-Huai-Hai regions), which was probably due to considerable difference in sample sizes (Table 4). More similarity of Shannon index between the Northwest regions (0.3752) and Southwest regions $(0.3615)$, but a little greater than that in Huang-Huai-Hai regions (0.3405), indicated that collections from the three regions had very similar diversity of races, further implying the movement of urediniospores across large distances within wheat growing areas. The climatic conditions and wheat planting system favorable for rust fungi to survive year-round in both the Southwest and Northwest regions are probably the main reasons for greater diversity than that in the Huang-Huai-Hai regions.

\section{DISCUSSION}

The wheat stripe rust population in China appears to be geographically isolated from those in other countries in terms of virulence evolution $(3,4,27,28,44,45)$. It is presumed that mutation and local adaptation to the host resistance is the basis for the occurrence of newly virulent types of this pathogen. Empirical data suggested that several mutation events from avirulence to virulence or the opposite direction for certain resistance loci may occur independently in the $P$. striiformis f. sp. tritici population of China (Fig. 4). A range of races was detected during the period of this study, and each newly emerging race was closely related to pre-existing ones. For example, CYR29 possessed virulence for wheat lines that carried resistance gene $\operatorname{Yr} 9$, and most likely evolved from a single mutation in CYR25. Both CYR30 and Su11-7, detected in 1991 and 1994, separately displayed great similarities to CYR29 with the exception of increased virulence for Hybrid 46 and Suwon 11, respectively, which was considered to have arisen from a single mutation in CYR29. Basically, there have been two major

Fig. 4. Diagrammatic progress and presumed mutation events of important races of Puccinia striiformis $\mathrm{f}$. $\mathrm{sp}$. tritici in China in the past four decades. 
courses of virulence evolution in the $P$. striiformis f. sp. tritici population in China since the 1990s. One was directed at the specific virulence for Hybrid 46 (group $\mathrm{HyG}$ ) with virulence to Hybrid 46 and Suwon 11, and another was subject to the specific virulence for Suwon 11 alone (group SuG) (Fig. 4). CYR31 and CYR32 with the combined virulence to Hybrid 46, Suwon 11, and Lovrin 10/Lovrin 13 were first found in the Southwest regions in 1993 and 1994, respectively, which were consistent with CYR30. CYR33 with the combined virulence to Suwon 11 and Lovrin 10/Lovrin 13 has most likely arisen from a mutation of virulence for Jubileijna 2 and Kangyin 655 in Su11-7. Alternatively, it would be possible that CYR33 came from CYR32 with loss of virulence for Hybrid 46 based on the emerging sequence and similarity of virulence spectra. Since the 1980s, Fan6 and its derivatives with resistance from Hybrid 46 have become the leading cultivars in the Southwest region and mid-valley of the Yangtz River, simultaneously the cultivars with the same type of resistance as Suwon 11 have probably been planted in the Northwest region in recent years, which provided favorable conditions for the directional selection of new races for Hybrid 46 and Suwon 11, leading to local adaptation and widespread $\mathrm{HyG}$ and $\mathrm{SuG}$. In conclusion, mutation of stripe rust fungus from avirulence to virulence or the opposite direction for certain loci and local adaptation to the host resistance is the basic cause of the occurrence of new virulence types. This hypothesis is consistent with the evolution in the northwest European P. striiformis $\mathrm{f}$. sp. tritici population described using amplified fragment length polymorphism markers by Hovmoller and Justesen (11) and that in Australasia described by Wellings and McIntosh $(39,40)$. In addition, parasexuality or somatic recombination events between isolates may be an alternative way to yield new races (19). Based on the results of this study, CYR32 and CYR33 became the predominant races in recent years, and this may be attributed to a relatively greater parasitic fitness of both races on leading commercial cultivars (29).

It has been found that southern Gansu and northwestern Sichuan are the most important over-summering areas of $P$. striiformis f. sp. tritici. These regions have important roles in providing inoculum for the autumn-sown wheat in the eastern areas $(1,2,4,14,43)$. Historically, almost all Chinese races were first detected in these regions $(31,32,35,37,41)$. Two main hypotheses can be proposed on the origin of rust virulence in those regions. Firstly, wheat planting systems in these zones are favorable for rust fungi to survive yearround. In southern Gansu, wheat can be grown from lowland valleys at $1,000 \mathrm{~m}$ to highland terraces at $2,500 \mathrm{~m}$, and sowing periods vary from early September in the highlands to late October in the lowlands, whereas harvest occurs from mid-June in the lowlands to late July in the highlands. At elevations above $1,500 \mathrm{~m}$, stripe rust inoculum can over-summer on volunteer wheat seedlings that provide a "green bridge" and inoculum transfer from latematured wheat to early-sown seedlings $(2,3,14,34)$. Therefore, there is no restriction of inoculum transfer between successive cropping cycles. Pathogen inoculum can also over-winter at elevations below $1,800 \mathrm{~m}$, where temperatures are less drastic for pathogen survival. During the spring, urediniospores would migrate from the over-wintering areas to the mountain terraces and so allow a continuing movement of viable pathogen inoculum. In northwestern Sichuan, such as the Aba district, where wheat is cultivated from 1,170 to $3,300 \mathrm{~m}$, there exists a "yearround wheat" cropping cycle from August to September of the following year (42). The overlapping period between preceding and succeeding wheat crops provides an ideal condition for local over-summering of $P$. striiformis f. sp. tritici. The areas of altitude 1,500 to $1,800 \mathrm{~m}$ in southern Gansu and 1,900 to 2,500 $\mathrm{m}$ in northwestern Sichuan are considered the "hotspots" for the wheat stripe rust pathogen, where over-summer and over-winter occurs. A large population of $P$. striiformis f. $\mathrm{sp}$. tritici survives the summer on the latematured wheat or volunteer seedlings and the winter on the susceptible winter wheat in southern Gansu and northwestern $\mathrm{Si}$ chuan, thus creating a large reservoir for potential mutations for new virulence and subsequent selection by those cultivars with specific resistance genes. Secondly, the climatic conditions (low temperatures and high humidity) are ideal for infection and reproduction of $P$. striiformis f. sp. tritici urediniospores in southern Gansu and northwestern Sichuan. For example, in the half mountain areas of elevation 1,800 $m$ in southern Gansu, the annual averages for temperature $\left(8.5^{\circ} \mathrm{C}\right)$, annual precipitation $(533.9 \mathrm{~mm})$, rainy days (103.3 days), dew days (92.5 days), and foggy days (7.3 days) are ideal for stripe rust epidemics. The monthly average temperatures in the hottest July and the coldest January are 18.3 and $-3.9^{\circ} \mathrm{C}$, respectively (data sourced from a local weather station). In northwestern Sichuan, such as the Aba district, it is $17.5^{\circ} \mathrm{C}$ in July and $-0.9^{\circ} \mathrm{C}$ in January in the areas approximating 2,400 $\mathrm{m}$ (42). These low temperature and high humidity conditions facilitate year-round survival of the pathogen, leading to rapid reproduction of the pathogen and consequent huge inoculum supply. It was reported that $P$. striiformis f. sp. tritici urediniospores could complete the reinfection of 16 to 18 generations in the areas of elevation $1,700 \mathrm{~m}$ during March to November annually (14).
The Chinese population of $P$. striiformis f. sp. tritici exhibited great diversity with a complex virulence structure, which could be mostly attributed to the existence of diversity of wheat cultivars planted in various wheat growing regions. Since the 1990s, developing wheat cultivars with slow-rusting or durable resistance to stripe rust has become a top priority in the wheat breeding programs in Sichuan, Gansu, Henan, Shaanxi, and Yunnan provinces $(10,50)$. More than 90 wheat cultivars were planted in the Tianshui region of Gansu province, with total areas of 144,700 and 143,300 ha in 2005 and 2006, respectively (data from Tianshui Bureau of Agriculture). Cultivars with different resistance genes or gene combinations would be expected to select different virulence patterns. However, despite a multitude of $P$. striiformis f. sp. tritici races being detected across the country over the 5-year period of this study, only a few races such as CYR32, CYR33, Su11-4, and Su11-7 occurred with relatively high frequencies, suggesting that the situation of relatively simple resistance in leading wheat cultivars has not been dramatically improved, which is supported by the postulation of resistance genes in Chinese commercial cultivars $(13,25)$.

Higher diversity for races in the Northwest and Southwest regions than in the Huang-Huai-Hai region has been revealed in this study. This further supports the hypothesis that the regions of southern Gansu and northwestern Sichuan are the centers of origin for new virulence variation and diversity in the Chinese P. striiformis f. sp. tritici population. Alternate strategies, such as biodiversity (genetic diversity and crop diversity), should be considered as priority strategies for developing sustainable disease control nationwide. Improving cultivar resistance and deploying resistance genes would be expected to be implemented in the near future.

The relative Shannon index was used to avoid bias in comparisons between samples of greatly different sizes, which reflects both richness (number of races) and evenness (similarity of race frequencies) in the sample. However, diversity differences among populations can be only partially explained by Shannon's index between corresponding diversities within the population. Shannon's index considers nonidentical phenotypes as equally distinct and ignores the number of differences in virulence isolates (18). Nevertheless, some isolates exhibit distinct response patterns, while others are quite similar. Kosman (12) suggested two new analyses for assessing genetic variation between and within populations that take into account both race frequencies and degrees of similarity among distinct races $(12,18)$. In this study, a major restriction was that many of the resistance genes in Chinese differential 
genotypes are unknown. Therefore, further work would be expected to survey and monitor the virulence variation of stripe rust population between years and regions using near isogenic lines or monogenic lines with different genes for stripe rust resistance as differentials, combined with their molecular polymorphisms.

\section{ACKNOWLEDGMENTS}

Colin R. Wellings, Plant Breeding Institute at University of Sydney provided a critical and conscientious review of the previous version of this paper prior to submission. His comments, suggestions, and editorial revisions greatly improved the quality of the paper. The authors express their grateful appreciation for his kindness, enthusiasm, time, and efforts. We also thank Ravi P. Singh at CIMMYT for his critical reading and review of the manuscript. We thank all members of the Chinese National Wheat Rust Collaboration Group for their contribution to this project and cooperative fellows in different regions in China for providing samples and information. Financial support from the Ministry of Agriculture and Ministry of Science and Technology, P. R. China are gratefully acknowledged. This study was partially supported by National '973' Program (Grant No. 2006CB100203), National '863' Plan (Grant No. 2006AA10Z429), and National Key Technologies Research and Development Program (Grant No. 2006BAD02A16).

\section{LITERATURE CITED}

1. Chen, S. M., Wang, K. N., Li, Z. Q., Liu, H. W., Zeng, S. M., Lu, D. Y., Xie, S. X., Wang, J. Q., Ruan, S. K., Huang, G. M., Wu, L. R., Song, W. Z., Yuan, W. H., Liu, X. K., Hong, X. W., and Yang, S. C. 1989. Epidemic system of wheat stripe rust in China. In: Brief Introduction of Chinese National Natural Science Achievements in 1987. Committee of Chinese Natural Science Awards, eds. (In Chinese.) Metallurgy Industry Press, Beijing.

2. Chen, W. Q., and Xie, S. X. 1999. Ecological zones and inter-regional dispersal of wheat stripe rust in China. Pages 276-277 in: Research Progress in Plant Protection and Plant Nutrition. F. Z. Hong and K. X. Li, eds. China Agriculture Press, Beijing.

3. Chen, W. Q., Xu, S. C., Liu, T. G., Lin, R. M., Wu, L. R., Jin, S. L., and Cao, S. Q. 2007. Wheat stripe rust and its prospects for ecological control in China. Proc. 16th Int. Plant Prot. Congr., Vol. 2, 11D-1, Glasgow, UK.

4. Chen, W. Q., Xu, S. C., and Wu, L. R. 2007. Epidemiology and sustainable management of wheat stripe rust caused by Puccinia striiformis West. in China: A historical retrospect and prospect. (In Chinese with English abstr.) Sci. Agric. Sin. 40:177-183.

5. Chen, X. M. 2005. Epidemiology and control of stripe rust (Puccinia striiformis f. sp. tritici) on wheat. Can. J. Plant Pathol. 27:314-337.

6. Fang, C. T. 1944. Physiological specialization of Puccinia glumarum Erikss. and Henn. In China. Phytopathology 34:1020-1024.

7. Fang, C. T., and Chen, N. Y. 1955. Varietal resistance of wheat to stripe rust at the seedling stage and the variability of causal organism. (In Chinese with English abstr.) Acta Phytopathol. Sin. 1:155-168.

8. Gassner, G., and Straib, W. 1932. Die bestimmung der biologischen rassen des weizengelbostes (Puccinia glumarum f. sp. tritici (Schmidt.) Erikss. Und Henn.). Arb. Biol. Reichsanstalt Land Forstwirtschaft 20:141163.

9. Groth, J. V., and Roelfs, A. P. 1987. The concept and measurement of phenotypic diversity in Puccinia graminis on wheat. Phytopathology 77:1395-1399.

10. He, Z. F., Rajaram, S., Xin, Z. Y., and Huang,
G. Z. 2001. A history of wheat breeding in China. CIMMY, Mexico, D.F.

11. Hovmoller, M. S., and Justesen, A. F. 2007. Rates of evolution of avirulence phenotypes and DNA markers in a northwest European population of Puccinia striiformis $\mathrm{f}$. sp. tritici. Mol. Ecol. 16:4637-4647.

12. Kosman, E. 1996. Difference and diversity of plant pathogen populations: A new approach for measuring. Phytopathology 86:11521155.

13. Li, Z. F., Xia, X. C., Zhou, X. C., Niu, Y. C., He, Z. H., Zhang, Y., Wan, A. M., Wang, D. S., Chen, X. M., Lu, Q. L., and Singh, R. P. 2006. Seedling and slow rusting resistance to stripe rust in Chinese common wheats. Plant Dis. 90:1302-1312.

14. Li, Z. Q., and Zeng, S. M. 2002. Wheat rust in China. (In Chinese.) China Agricultural Press, Beijing.

15. Line, R. F. 2002. Stripe rust of wheat and Barley in North America: A restrospective historical review. Annu. Rev. Phytopathol. 40:75118.

16. Line, R. F., and Chen, X. M. 1995. Successes in breeding for managing durable resistance to wheat rust. Plant Dis. 79:1254-1255.

17. Lu, S. Y., Fan, K. F., Shia, S. M., Mu, W. T., Kong, S. L., Yang, T. M., Wang, K. N., and Lee, S. P. 1956. Studies on stripe rust of wheat, I. Physiologic specialization of Puccinia glumarum (Schmidt) Erikss. \& Henn. (In Chinese with English abstr.) Acta Phytopathol. Sin. 2:153-166.

18. Manisterski, J., Eyal, Z., Ben-Yehuda, P., and Kosman, E. 2000. Comparative analysis of indices in the study of virulence diversity between and within populations of Puccinia recondita f. sp. tritici in Israel. Phytopathology 90:601-607.

19. Mboup, M., Leconte, M., Gautier, A., Wan, A., Chen, W., de Vallavieille-Pope, C., and Enjalbert, J. 2008. Evidence of genetic recombination in Chinese wheat yellow rust populations in the over summering area. Fungal Genet. Biol. 46:299-307.

20. McIntosh, R. A., and Brown, G. N. 1997. Anticipatory breeding for resistance to rust diseases in wheat. Annu. Rev. Phytopathol. 35:311-326.

21. McIntosh, R. A., Hart, G. E., Devos, K. M., Rogers, W. J., Morris, C. F., Appels, R., and Anderson, O. D. 2007. Catalogue of gene symbols for wheat: 2007 supplement. http:// shigen.lab.nig.ac.jp//wheat/komugi/top/top.jsp.

22. McIntosh, R. A., Yamazaki, Y., Devos, K. M., Dubcovsky, J., Rogers,W. J., and Appels, R. 2003. Catalogue of gene symbols for wheat. Proc. 10th Int. Wheat Genet. Sympos., Vol. 1, Instituto Sperimentale per la Cerealcoltura, Roma, Italy.

23. McVey, D. V., Nazim, M., Leonard, K. J., and Long, D. L. 2004. Patterns of virulence diversity in Puccinia triticina on wheat in Egypt and the United States in 1998-2000. Plant Dis. 88:271-279.

24. Ministry of Agriculture, P. R. China. 2007. China Agriculture Annual 2006. (In Chinese.) http://www.agri.gov.cn/sjzl/nynj/NYNJ200602. p. 177.

25. Niu, Y. C., Qiao, Q., and Wu, L. R. 2000. Postulation of resistance genes to stripe rust in commercial wheat cultivars from Hennan, Shandong, and Anhui provinces. (In Chinese with English abstr.) Acta Phytopathol. Sin. 30:122-128.

26. Roelfs, A. P., Singh, R. P., and Saari, E. E. 1992. Rust diseases of wheat: Concepts and methods of disease management. CIMMYT, Mexico, D.F

27. Stubbs, R. W. 1985. Stripe rust. Pages 61-101 in: The Cereal Rusts. Vol. II. A. P. Roelfs and W. R. Bushnell, eds. Academic Press, New York
28. Stubbs, R. W. 1988. Pathogenicity analysis of yellow (stripe) rust of wheat and its significance in a global context. Page 23-38 in: Breeding Strategies for Resistance to the Rust of Wheat. N. W. Simmonds and S. Rajaram, eds. CIMMYT, Mexico, D.F.

29. Tian, H. M., Liu, T. G., Gao, L., and Chen, W. Q. 2008. Parasitic fitness of four major prevalent races of Puccinia striiformis $\mathrm{f}$. sp. tritici in China. (In Chinese with English abstr.) Acta Phytopathol. Sin. 38:599-606.

30. Wan, A. M., Chen, X. M., and He, Z. H. 2007. Wheat stripe rust in China. Aust. J. Agric. Res. 58:605-619.

31. Wan, A. M., Niu, Y. C., Wu, L. R., Yuan, W. H., Li, G. B., Jia, Q. Z., Jin, S. L., Yang, J. X., Li, Y. F., and Bi, Y. Q. 1999. Physiologic specialization of wheat stripe rust in China during 1991-1996. (In Chinese with English abstr.) Acta Phytopathol. Sin. 29:15-21.

32. Wan, A. M., Wu, L. R., Jia, Q. Z., Jin, S. L. Wang, B. T., Li, G. B., Yang, J. X., Yao, G., Bi, Y. Q., and Yuan, Z. Y. 2003. Pathogenic changes of stripe rust fungus of wheat in China during 1997-2001. (In Chinese with English abstr.) Acta Phytopathol. Sin. 33:261-266.

33. Wan, A., Zhao, Z., Chen, X., He, Z., Jin, S., Lia, Q., Yao, G., Yang, J., Wang, B., Li, G., Bi, Y., and Yuan, Z. 2004. Wheat stripe rust epidemic and virulence of Puccinia striiformis $\mathrm{f}$. sp. tritici in China in 2002. Plant Dis. 88:896904.

34. Wang, J. Q., and Tai, S. K. 1965. Study on oversummering of wheat yellow rust fungus in South Gansu. (In Chinese with English abstr.) Acta Phytopathol. Sin. 8:1-10.

35. Wang, K. N., Hong, X. W., Si, Q. M., Wang, J. X., and Shen, J. P. 1963. Studies of the physiology specialization of stripe rust of wheat in China. (In Chinese with English abstr.) Acta Phytophylog. Sin. 2:23-36.

36. Wang, K. N., Hong, X. W., Wu, L. R., Xie, S. X., Meng, Q. Y., and Chen, S. M. 1986. The analysis of the resistance of varieties in the wheat stripe rust nurseries during 1951-1983. (In Chinese with English abstr.) Acta Phytophylog. Sin. 13:117-124.

37. Wang, K. N., Wu, L. R., Meng, Q. Y., Xie, S. X., and Lu, D. Y. 1986. On the physiological specialization of stripe rust of wheat in China during the year 1975-1984. (In Chinese with English abstr.) Acta Phytopathol. Sin. 16:7985.

38. Wang, K. N., Xie, S. X., Liu, X. K., Wu, L. R., Wang, J. X., and Chen, Y. L. 1988. Progress in studies on wheat stripe rust in China. (In Chinese with English abstr.) Sci. Agric. Sin. $16: 80-85$.

39. Wellings, C. R. 2007. Puccinia striiformis in Australia: A review of the incursion, evolution, and adaptation of stripe rust in the period 1979-2006. Aust. J. Agric. Res. 58:567-575.

40. Wellings, C. R., and McIntosh, R. A. 1990 Puccinia striiformis f. sp. tritici in Australasia: Pathogenic changes during the first ten years. Plant Pathol. 39:316-325.

41. Wu, L. R., Yang, H. A., Yuan, W. H., Song, W. Z., Yang, J. X., Li, Y. F., and Bi, Y. Q. 1993. On the physiological specialization of stripe rust of wheat in China during 1985-1990. (In Chinese with English abstr.) Acta Phytopathol. Sin. 23:269-274.

42. Xie, S. X., Chen, Y. L., Chen, W. Q., Wang, K. L., Ding, X. P., He, X. L., Pu, J. C., Shi, W. Q., Ou, Y., and Du, D. M. 1988. Occurrence and epidemics of wheat stripe rust in Abazhou. (In Chinese with English abstr.) Acta Phytophylog. Sin. 15:85-91.

43. Xie, S. X., Chen, W. Q., Chen, Y. L., Wang, K. N., Lin, X. L., and Yang, Z. H. 1992. On the dispersal of wheat stripe rust (Puccinia striiformis West.) in Longnan prefecture and abazhou. (In Chinese with English abstr.) Acta Phytopathol. Sin. 22:138-143. 
44. Yang, H. A., and Stubbs, R. W. 1990. Gene postulation for wheat stripe rust resistance on Chinese differential hosts. (In Chinese with English abstr.) Acta Phytopathol. Sin. 17:6772 .

45. Zeng, S.-M., and Luo, Y. 2006. Long-distance spread and interregional epidemics of wheat stripe rust in China. Plant Dis. 90:980-988.

46. Zhao, W. S., and Xu, S. C. 2005. Genetics of stripe rust resistance in wheat cultivar Virgilia.
(In Chinese with English abstr.) Acta Phytopathol. Sin. 32:348-352.

47. Zhao, W. S., Xu, S. C., Zhang, J. Y., and Wan, A. M. 2004. Inheritance of stripe rust resistance in wheat cultivar Jubilejina 2. (In Chinese with English abstr.) Acta Phytopathol. Sin. 31:127-133.

48. Zhao, W. S., Xu, S. C., Zhang, J. Y., and Wan, A. M. 2006. Inheritance of stripe rust resistance in wheat cultivar Kangyin 655. (In Chi- nese with English abstr.) Acta Phytopathol Sin. 33:22-26.

49. Zhou, X. C., Wu, L. R., Song, J. R., and Jin, S L. 2008. Control of wheat stripe rust based on genetic diversity of cultivars in Longnan. (In Chinese with English abstr.) Acta Phytopathol Sin. 35:97-101.

50. Zhuang, Q. S. 2003. Chinese wheat improvement and pedigree analysis. (In Chinese.) China Agricultural Press, Beijing. 